\title{
UPAYA MENINGKATKAN HASIL BELAJAR DENGAN MENGGUNAKAN MULTIMEDIA PADA MATERI SISTEM KOORDINASI
}

\author{
Devi Putri Rozalina \\ SMA Negeri 3 Bogor
}

Email: cvichayang@yahoo.com

\begin{abstract}
ABSTRAK
Perkembangan teknologi memberikan dampak terhadap beberapa aspek, salah satunya pada aspek Pendidikan. Salah satu perkembangan teknologi dalam pendidikan adalah perkembangan multimedia berupa buku berbasis digital. Perkembangan tersebut memberikan arti yang sangat besar bagi pembelajaran. Salah satu materi yang menggunakan buku digital adalah materi sistem koordinasi. Penelitian tindakan kelas ini bertujuan untuk meningkatkan hasil belajar siswa pada materi sistem koordinasi dengan menggunakan multimedia berupa buku digital. Penelitian ini terdiri dari 2 siklus. Hasil penelitian didapatkan data bahwa terjadi peningkatan hasil belajar siswa dari rata-rata sebelum perlakuan adalah 68 menjadi rata-rata 87. Kesimpulan dari penelitian ini adalah penggunaan multimedia berupa buku digital dalam pembelajaran dapat meningkatkan hasil belajar siswa dalam materi sistem koordinasi.
\end{abstract}

Kata kunci: Multimedia, buku digital, hasil belajar

\section{PENDAHULUAN}

Kemajuan teknologi dibidang ITechno saat ini berkembang sangat pesat. Berbagai macam produk berbasis ITechno seperti laptop, computer, handphone dan tablet bermunculan dengan berbagai spesifikasi. Kemajuan di bidang ITechno berdampak pada berbagai lini kehidupan seperti pergeseran status sosial, akses informasi yang cepat, dan informasi yang terupdate. Pendidikan merupakan salah satu bagian yang mendapatkan pengaruh dari kemajuan Itechno. Akses informasi yang cepat dan updatenya ilmu pengetahuan sangat dibutuhkan dalam arus informasi saat ini. Karena ilmu pengetahuan terus berkembang sehingga akses informasi tersebut harus tersampaikan dengan cepat.

Pembelajaran Biologi khususnya bidang sistem koordinasi merupakan subjek yang sangat cepat perkembangannya. Penemuan penemuan terbaru dibidang sistem koordinasi menjadi suatu hal yang memperkaya ilmu tersebut. Namun disisi lain materi sistem koordinasimerupakan materi yang sangat sulit karena kompleksitas materi yang tinggi dan materi tersebut abstrak, sehingga membuat siswa menjadi kurang memahami materi sistem koordinasi secara mendalam. Berdasarkan hasil analisis kebutuhan bahwa sebanyak 54\% siswa menyatakan materi sistem koordinasi merupakan subjek materi tersulit di pembelajaran Biologi kelas XII. Materi sistem koordinasi merupakan materi yang aplikatif namun sangat mendalam. Aspek gen pada mahluk hidup berdampak dalam pengaturan tubuh secara menyeluruh. Materi sistem koordinasi dapat merangsang siswa dalam berpikir secara analisis dalam mengaitkan fenomena-fenoma yang terjadi pada manusia dan kaitan dalam ekspresi gen tertentu dalam pengaturan tubuh.

Paradigma pemebalajaran saat ini berdasarkan kurikulum yang diterapkan menuntut suatu kemandirian siswa baik dalam pembelajaran dikelas, praktikum di laboratorium, dan di rumah. Sehingga dibutuhkan suatu sumber belajar yang dapat menunjang siswa dalam belajar ditempat apapun dan kapanpun. Sumber belajar yang tepat dalam 
menunjang pembelajaran mandiri adalah modul. Karena modul memiliki keunggulan dibandingkan buku. Karena modul dilengkapi petunjuk belajar dan informasi pendukung yang tidak dimiliki buku. Petunjuk belajar dapat membimbing siswa untuk belajar secara mandiri. Bukan hanya menunjang dalam pembelajaran di kelas maupun di rumah, namun juga dibutuhkan modul yang dilengkapi dengan pedoman praktikum yang dapat menunjang siswa untuk melakukan praktikum sederhana materi sistem koordinasi secara mandiri.

Kemajuan teknologi saat ini dan tuntutan diperlukannya suatu sumber belajar yang dapat menunjang siswa dalam pembelajaran secara mandiri maka diperlukan suatu pengembangan modul berbasis multimedia yang dapat menunjang siswa belajar secara mandiri. Modul tersebut membahas materi sistem koordinasi yang merupakan materi yang kompleks dan selalu update. Sehingga modul multimedia yang dikembangkan harus dapat terkases dengan materi-materi terbaru di internet. Penerapan modul multimedia yang dikembangkan diharapkan dapat meningkatkan kemampuan kognitif siswa dalam pembelajaran berkolaborasi. Mixed antara pembelajaran secara konvensional dengan penerapan modul multimedia dalam model Collaborative mLearning. Tujuan akhirnya adalah mengukur efektivitas dalam penerapan modul multimedia berbasis multimedia pada materi sistem koordinasi untuk meningkatkan kemampuan kognitif siswa dalam tingkatan analisis melalui model Collaborative mLearning.

Modul

Modul adalah sebuah sumber belajar yang ditulis dengan tujuan agar siswa dapat belajar secara mandiri tanpa atau dengan bimbingan guru, sehingga modul mencakup: (1) petunjuk belajar; (2) kompetensi yang dicapai; (3) informasi pendukung; (4) latihan-latihan; (5) petunjuk kerja atau lembar kerja; (6) evaluasi (Majid, 2008). Modul adalah kegiatan program belajar-mengajar yang dapat dipelajari oleh siswa dengan bantuan yang minimal dari guru pembimbing, meliputi perencanaan tujuan yang akan dicapai secara jelas, penyediaan materi pelajaran, alat yang dibutuhkan, serta alat untuk mengukur keberhasilan siswa. Modul memiliki komponen petunjuk belajar dan informasi pendukung. Komponen tersebut merupakan keunggulan yang dimiliki modul dibandingkan dengan buku (Dikmenum, 2005).

\section{Modul Berbasis Multimedia}

Modul yang dikembangkan adalah modul berbasis multimedia. Modul berbasis multimedia dapat merupakan kombinasi teks, grafik, animasi, suara, dan video. Kombinasi ini dapat difasilitasi dengan media berbasis ITechno seperti komputer, laptop, smartphone, dan sejenisnya. Hard (2009) menyatakan bahwa multimedia dapat ditinjau dari tiga sudut pandang, yaitu: pertama, dari pandangan pengiriman media, maka multimedia didefinisikan sebagai dua atau lebih alat-alat pengiriman. Contoh: layar komputer dan amplified speaker, proyektor dan suara penceramah. Kedua, multimedia dari pandangan mode presentasi, yang berarti multimedia sebagai representasi verbal atai pictorial (gambar), Contohnya, teks on-screen dan animasi. Teks cetak dan ilustrasi. Dan terakhir, dari pandangan modalitas sensori, multimedia didefinisikan sebagai media yang dapat mengaktifkan indra auditori atau visual, contohnya: narasi dan animasi; ceramah dan slide.

\section{Collaborative mLearning models}

Modul berbasis multimedia yang digunakan dalam pembelajaran tepat menggunakan model Collaborative mLearning models. Collaborative learning adalah interkasi sosial.Collaborative adalah suatu model yang meningkatkan kemampuan memori, meengurangi kesalahan, dan meningkatkan motivasi. Komunikasi bukan hanya sekedar transfer informasi tetapi interkasi yang memungkiunkan proses memahami dan menciptakan. Peserta didil yang terlibat tatap muka dan online, dan merefleksikan melalaui diskusi, komunitas dalam pembelajaran akan terbentuk. Dengan menggabungkan antara pemeblajaran secara konvensional dengan teknologi dapat menambah kemampuan siswa dalam memahami materi pembelajaran (Dorothy et all, 2013). 


\section{METODE PENELITIAN}

Penelitian ini merupakan penelitian tindakan kelas (PTK). Penelitian ini menggunakan 2 siklus. Sampel penelitian ini adalah siswa kelas XI IPA SMA Negeri 3 Bogor pada pembelajaran Biologi dengan materi Sistem Koordinasi.

\section{HASIL DAN PEMBAHASAN \\ Penerapan Modul Multimedia dalam Pembelajaran Berkolaborasi}

Pada penelitian ini dilakukan dengan 2 siklus, sebelum melakukan pembelajaran siswa dibagikan tes hasil belajar untuk melihat kemampuan awal siswa didapatkan data rata-rata sebesar 68, lalu dilanjutkan pembelajaran dengan menggunakan media pada materi sistem koordinasi pada sub materi saraf dan indera. Siswa mengalami peningkatan rata-rata kelas sebesar 75. Lalu dilanjutkan dengan sub materi hormon yang merupakan sub materi yang cukup abstrak. Materi hormon merupakan salah satu sub materi yang sulit dengan menggunakan media berupa buku digital yang dilengkapi dengan video, siswa menjadi lebih semangat untuk belajar dan dapat memahami materi dengan baik, terlihat dari hasilnya adalah mengalami kenaikan rata-rata kelas pada siklus II yaknimenjadi 87 .

Hasil belajar dalam pembelajaran Biologi mencakup hasil pembelajaran kognitif (pengetahuan), afektif (sikap), dan psikomotorik (keterampilan). Ranah kognitif dibagi dalam beberapa tingkatan menurut Anderson dan Krathwohl yakni mengingat (remembering), memahami (understanding), mengaplikasikan (applying), menganalisis (Analysing), mengevaluasi (evaluating), dan menciptakan (creating). Tingkatan tertinggi dalam proses berpikir adalam menciptakan (Anderson, 2002).

Dalam pembelajaran siswa mengalami banyak kesulitan dalam pembelajaran. Oleh karena itu guru harus dapat mencari suatu solusi untuk meningkatkan kualitas pembelajaran. Bisa menggunakan beberapa teknik dalam pembelajaran ataupun dengan memperhatikan empat komponen dasar dalam pembelajaran kondisi belajar, karakteristik siswa, material, dan tes hasil belajar. Kondisi belajar adalah keadaan atau suasana dalam pembelajaran. Untuk menghasilkan pembelajaran yang baik maka diperlukan suasana yang kondusif. Karakteristik siswa mencakup dalam umur dan latar belakang kognitif. Material mencakup dalam berbagai sumber belajar dan literatur yang digunakan dalam pembalajaran (Dunlosky, 2013).

Salah satu sumber belajar yang dapat digunakan dalam menunjang pembelajaran adalah modul. Modul memiliki komponen petunjuk belajar dan informasi pendukung. Komponen tersebut merupakan keunggulan yang dimiliki modul dibandingkan dengan buku. Modul dibuat secara sistematis, operasional dan terarah untuk digunakan oleh siswa dalam meningkatkan efisiensi dan efektifitas pembelajaran. para siswa dapat mengikuti program pengajaran sesuai dengan kecepatan dan kemampuan sendiri, lebih banyak belajar mandiri, dapat mengetahui hasil belajar sendiri, dan menekankan penguasan bahan pelajaran secara optimal (mastery learning) yaitu dengan penguasaan minimal $80 \%$. Dengan menggunakan modul pembelajaran lebih efektif, siswa belajar secara individual atau mandiri untuk dapat memahami pembelajran sesuai dengan kemampuannya. Berdasarkan hasil penelitian didapatkan bahwa pembelajaran dengan modul lebih efektif dibandingkan dengan pembelajaran secara tradisional (Ali, 2010).

Penerapan modul dapat dilakukan pada beberapa model. Penggunaan modul dalam berbagai macam model seperti problem based learning, modullar teaching, ataupuncollaborative mobile learning. Pada model collaborative mobile learning, modul dibuat atau diintegrasikan dengan media $C M C$ (media berbasis komputer atau berbeasis multimedia). modul yang telah dibuat secara multimedia secara efektif dapat meningkatkan hasil belajar hingga 21.09 poin (Dewitt, 2014). Dalam perkembangannya modul dapat digunakan dalam jenjang pendidikan apapun, mulai dari secondary level hingga university level. Dalam mengkolaborasikan antara modul dengan e-learning menunjukan suatu nilai keefektivan yang signifikan. Siswa dapat belajar secara mandiri dan didukung oleh berbagai sumber. Baik berupa text, tatap muka, maupun video. Dengan menggabungkan dengan elearning pembelajaran lebih efektif dibuktikan dengan peningkatan nilai pretest dan posttest (Beck, 2012). Saat ini telah dikembangkan 
gabungan modul dengan teknologi berbasis komputer yang disebut dengan PTechLS module, seperti layaknya flip flopbook. Modul jenis ini akan lebih efektif dalam pembelajaran dan mampu meningkatkan minat siswa dalam belajar (Alias, 2015).

Dalam penggunaan modul tiap tingkatan menunjukan pembelajaran lebih efektif dibandingkan dengan cara tradisional (Sadig, 2014). Dalam penelitian lainnya menunjukan modul lebih komprehensif dibandingkan dengan pembelajaran secara tradisional. Dalam penelitian tersebut menunjukan nilai bahwa siswa laki-laki memiliki nilai yang lebih tinggi dibandingkan siswa perempuan dalam pembelajaran menggunakan modul (Malik, 2012).

\section{KESIMPULAN}

Berdasarkan penelitian yang dilakukandapat disimpulkan bahwa penerapan mediabuku digital dapat meningkatkan penguasaan konsep sistem koordinasi pada manusia.

\section{DAFTAR PUSTAKA}

Ali R, Ghazi SR, Khan MS, et al. Effectiveness of modular teaching in biology at secondary level. Canadian Center of Science and Education. 2010;6 (9): 49-54.

Alias N, DeWitt D, Rahman MNA, et al. Effectiveness of the biology PTechLS module in a Felda Science Centre. Malaysian Online of Journal Educational Technology. 2015;2 (4): 1-6.

Anderson, RW, Krathwohl DR. A taxonomy for learning, teaching, and assessing. A revision of Bloom's Taxonomy of Educational Objectives. 2002.

Beck M, Conner JM, Cruse K. An efficacy study of the biology. Educational Research Institute of America. 2012: 1-31.
Branch, RM. Instructional design: The ADDIE approach. Education, Springer. 2009 Campbell, Neil A., dkk. 2010. Biologi jilid 1: edisi kedelapan. Jakarta: Erlangga

Depdiknas. 2003. Pedoman Penulisan Modul. Jakarta. Direktorat Pendidikan Menengah Kejuruan, Dikdasmen-Depdiknas.

Dewitt D, Siraj Saedah, Alias N. Collaborative mLearning : a module for learning secondary school science. Educational Technology and Society. 2014;17 (1): 89101.

Dorothy, et all. 2013. Collaborative mLearning: A Module for Leraning Secondary Science. Journal Education Technology and Society, University of Malaya, Malaysia.

Dunlosky J, Rawson KA, Marsh EJ, et al. Improving student learning with effective learning techniques: promising directions from cognitive and educational. Psychlogocial Science. 2013;14(1): 4-58.

Elrod, Susan dan William, Stansfield. 2003. Genetika: Edisi keempat. Jakarta: Erlangga

Gall MD, Gall JP, and Borg WR. Educational Research. New York, NY: Pearson; 2007.

Hard E. Mayer. 2009. Multimedia learning prinsip-prinsip dan aplikasi. Yogyakarta: pustaka pelajar.

Majid, Abdul. 2008. Perencanaan Pembelajaran Mengembangkan Standar Kompetensi Guru. PT Remaja Rosdakarya, Bandung.

Malik SK. Effect modular and traditional approaches on student generale comprehension. Elixir Social Studies. 2012 (42): 6228-62231.

Sadiq S, Zamir S. Effectiveness of modular approach in teaching at university level. Journal in Education and Practice. 2014;5 (17): 103-109. 